\title{
Caps and tales
}

\section{JEFF COLLER}

Center for RNA Molecular Biology, Case Western Reserve University, Cleveland, Ohio 44106, USA

Happy birthday RNA! Twenty years—wow how time flies! I feel like I grew up (scientifically) with RNA. Back when the journal started in 1995, I was just a first year graduate student in Marv Wickens' lab. Having only been in the lab three months, I still remember all of us huddled in Marv's office when that first issue came out. Marv, as one of the first group of associate editors, was naturally very proud of this accomplishment. We didn't have PDFs back then and no library had a subscription to RNA, so each of us had to take turns looking through Marv's copy. Of course, since it was his copy and the first of its kind we were terrified of ripping a page. I wonder how my future would have turned out if I had torn right through Olke Uhlenbeck's perspective on "Keeping RNA Happy." Probably nothing. Knowing Marv he just would have used it as some inside joke during a talk - "RNA is NOT Happy, Jeff" —or he would have referred to me as coprolite or some other sesquipedalian dirty word. Nonetheless, I am happy to report the issue was returned unscathed and Marv is still my friend, my good friend. And that's what I really wanted to highlight in this perspective-friendship. Others will talk about the field and how things have changed and what we might predict will happen in the next 20 years, but in these past two decades what I have discovered more than anything is friendship and kindness within the RNA Society. In these turbulent times of budget cuts and funding issues, perhaps it is important to reflect on what makes science fun-people, people we call friends.

Those first few years of RNA were rocky (much like my graduate career). Issues were delayed (my data stunk). People questioned its success (and my graduation). But somehow, RNA (and I) made it through those trying times. And as time went by RNA began to take on a life of its own. Like $R N A$, I also survived those tremulous and awkward days. In the case of $R N A$, its success was a result of the dedication by Society members and Tim Nilsen. As for me, I owe my survival to Marv, Madison, Roy Parker, and Tim. I was fortunate to be a graduate student in Madison during the '90s and then a post-doc with Roy after that. I attended every RNA society meeting held on campus. Sitting in the Memorial Union as a young student was a close to a meta-

Corresponding author: jmc71@case.edu

Article and publication date are at http://www.rnajournal.org/cgi/doi/ 10.1261/rna.050534.115. Freely available online through the RNA Open Access option. physical experience as an agonistic scientist can experience. How many of us remember that front row? A who-is-who of the RNA Society. The auditorium was filled with heroes and rockstars. I still remember when the crystal structure of the ribosome was presented-my god how exciting! But most of all, I remember the terrace, the conversations, the science, and the friendships we created. My fellow graduate student, Amy Pasquinelli, used to make an industry out of color copying P.I. name tags so we could crash the meeting dinners. There must have been 40 Jim Dahlbergs doing the electric slide at every RNA Society banquet in Madison at that time. Of course the real Jim did the slide best. It was there on the terrace that I met so many of my good friends today —including my eventual life partner-Kristian Baker. But this is what the RNA Society was (and still is) — people loving what they do and just wanting to be part of a moment, sharing a unique love for this simple yet elegant molecule. The RNA journal is ultimately the best embodiment of this sentiment. Something we have embraced and thrown our energies in. Something we should all be proud of.

Eventually my life with RNA came full circle-starting where it began at Case Western Reserve University. While in Roy's lab, Kristian and I crashed a FASEB meeting on RNA transport held in Tucson in 2004. While sitting at the bar I ran into the most interesting character I have ever met. He offered me a cigarette, questioned my research, told me I was doing crap, and then offered me a job. It was Tim Nilsen. I started as an Assistant Professor in his Center for RNA Molecular Biology in the Fall of 2005. Since then, Kristian's lab and mine have grown and flourished. And so has my friendship with Tim and Pat. Tim has become a mentor and a friend. A friend who has help me cut down trees, invited me in his home, and has a cat named "Boo Boo." Kristian and I have found a home right in the epicenter of the RNA journal. Every day, we watch Tim and Ann Marie, constantly pouring over manuscripts, talking with authors, and handling reviews. It is truly a passion.

This brief stories may be boring to you, for this I apologize, but when Tim asked me to write this retrospective I could only think of one thing-my friends. Being in the RNA Center I have a bit of insider information. Tim selected the

(C) 2015 Coller This article, published in RNA, is available under a Creative Commons License (Attribution-NonCommercial 4.0 International), as described at http://creativecommons.org/licenses/by-nc/4.0/. 
cover of this issue because it was called "Group at Sea." It is really about all the faces of the RNA Society. So in thinking about the last 20 years I thought about what RNA and the Society really are-a community that is filled with good people. Twenty years is a long time to spend with a group of amazing people and not take time to thank them. So thank you. Thank you for your friendship, your kindness over the years, and the amazing things you do that make this field so fascinating. Here's to 20 more years and may the adventures continue. 

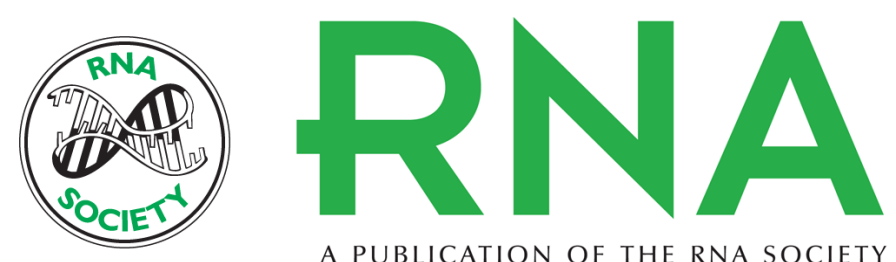

A PUBLICATION OF THE RNA SOCIETY

\section{Caps and tales}

Jeff Coller

RNA 2015 21: 588-589

Open Access Freely available online through the RNA Open Access option.

Creative This article, published in $R N A$, is available under a Creative Commons License

Commons (Attribution-NonCommercial 4.0 International), as described at

License http://creativecommons.org/licenses/by-nc/4.0/.

Email Alerting Receive free email alerts when new articles cite this article - sign up in the box at the Service top right corner of the article or click here.

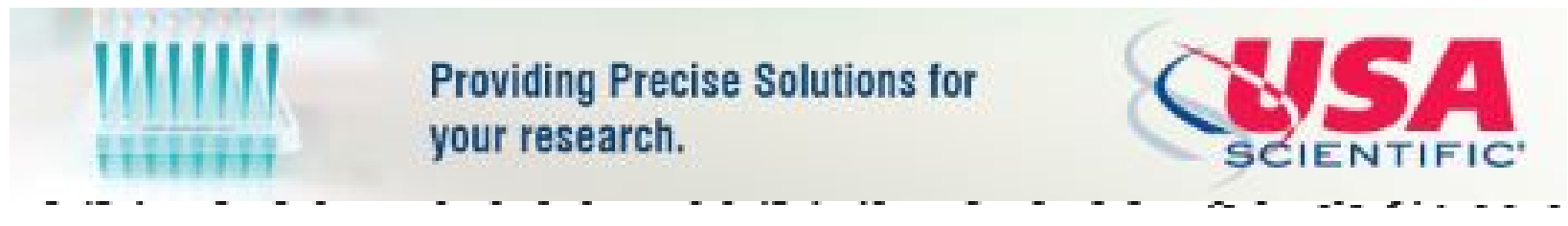

To subscribe to RNA go to:

http://rnajournal.cshlp.org/subscriptions

(C) 2015 Coller; Published by Cold Spring Harbor Laboratory Press for the RNA Society 